\title{
BRAIN CONCUSSION IN YOUNG ATHLETES: MAJOR PAIN POINTS
}

Klyuchnikov SO'1 , Feshchenko VS ${ }^{1,2}$, Zholinsky AV', Tarasova MS ${ }^{1 \otimes}$, Slivin AV², Efimov PV²

${ }_{1}^{1}$ Federal Research and Clinical Center of Sports Medicine and Rehabilitation of FMBA, Moscow, Russia

2 Pirogov Russian National Research Medical University, Moscow, Russia

\begin{abstract}
Numerous studies conducted in recent decades have generated vast amounts of knowledge on sport-related concussions. This review analyzes international data on pediatric and adolescent sport-related concussions. Drawing on the most recent research into the pathophysiology of brain concussions, the authors identify and discuss "pain points" associated with SRC, i.e. unsolved problems of diagnostic criteria, the use of modern neuroimaging modalities and promising biomarkers. Special attention is paid to the physiology of children and adolescents and predisposing factors important for developing adequate diagnostic and management strategies. The authors formulate problems that need to be solved in order to improve care for young athletes with brain concussions.
\end{abstract}

Keywords: elite athletes, brain concussion, youth sports

Funding: this review is part of the applied research study on the Clinical and prognostic significance of neurometabolic cascade for the development of delayed complications of hypoxic and traumatic brain injuries in athletes (Neurocascade-20, ID 76.35.41) conducted by the Federal Research and Clinical Center of Sports Medicine and Rehabilitation of FMBA under the State Assignment for years 2020-2021.

Author contribution: Klyuchnikov SO searched and analyzed the literature and contributed to writing the manuscript; Feshchenko VS contributed to writing the manuscript and edited the final version; Zholinsky AV edited the final version of the manuscript; Tarasova MS, Slivin AV, Efimov PV searched and analyzed the literature.

$\triangle$ Correspondence should be addressed: Maria S. Tarasova Raevskogo, 4, 121151, Moscow; tarasovams@sportfmba.ru

Received: 20.07.2021 Accepted: 12.08.2021 Published online: 17.09.2021

DOI: $10.47183 /$ mes.2021.026

\section{«БОЛЕВЫЕ ТОЧКИ» СОТРЯСЕНИЯ ГОЛОВНОГО МОЗГА У ЮНЫХ СПОРТСМЕНОВ}

\section{С. О. Ключников ${ }^{1}$, В. С. Фещенко ${ }^{1,2}$, А. В. Жолинский ${ }^{1}$, М. С. Тарасова ${ }^{1} \bowtie$, А. В. Сливин ${ }^{2}$, П. В. Ефимов ${ }^{2}$}

1 Федеральный научно-клинический центр спортивной медицины и реабилитации Федерального медико-биологического агентства, Москва, Россия

2 Российский национальный исследовательский медицинский университет имени Н. И. Пирогова, Москва, Россия

\begin{abstract}
Проведенные в последние десятилетия многочисленные исследования позволили получить большой объем научной инсормации по проблемам, связанным со спорт-ассоциированными сотрясениями головного мозга. В обзоре сделан анализ мировых данных о сотрясении головного мозга при занятиях спортом детей и юных спортсменов. Обсуждены «болевые точки» проблемы, к которым авторы относят сложные и нерешенные вопросы по критериям диагностики, применению современных методов нейровизуализации и перспективных биомаркеров с учетом новых научных данных о патофизиологических механизмах сотрясений головного мозга. Большое внимание уделено описанию физиологических особенностей детей и подростков и предрасполагающих факторов, значимых как для диагностики, так и для тактики ведения при возникновении этого состояния. Сформулированы актуальные задачи, решение которых необходимо для совершенствования практики спортивной медицины при сотрясении головного мозга у спортсменов детско-юношеского возраста.
\end{abstract}

Ключевые слова: спорт высших достижений, сотрясение головного мозга, детско-юношеский спорт

Финансирование: статья подготовлена в рамках прикладной научно-исследовательской работы «Клинико-прогностическое значение особенностей нейрометаболического каскада для развития отсроченных осложнений гипоксических и травматических повреждений мозга у спортсменов" (шифр темы: «Нейрокаскад-20», код темы: 76.35.41), выполненной ФГБУ ФНКЦСМ ФМБА России по государственному заданию на 2020-2021 год.

Вклад авторов: С. О. Ключников - поиск и анализ источников, написание текста; В. С. Фещенко - написание текста, общее редактирование; А. В. Жолинский - общее редактирование; М. С. Тарасова, А. В. Сливин, П. В. Ефимов - поиск и анализ источников.

$\triangle$ Для корреспонденции: Мария Сергеевна Тарасова

ул. Раевского, д. 4, 121151, г. Москва; tarasovams@sportfmba.ru

Статья получена: 20.07.2021 Статья принята к печати: 12.08.2021 Опубликована онлайн: 17.09.2021

DOI: $10.47183 /$ mes.2021.026

Numerous studies conducted in recent decades and the debate they sparked in top-tier scientific journals and at international forums have generated vast amounts of data on sport-related concussions (SRCs). A series of systematic reviews and metaanalyses have described how SRC characteristics vary depending on the type of sport, duration of training activities and sex. A wealth of diagnostic modalities, protocols, policies and laws have been elaborated to manage SRCs in a clinical setting [1, 2]. One would think that the amount of knowledge accrued to date and the advances in medical and biological technology would be enough to solve SRC-associated diagnostic and therapeutic challenges. Yet many of the complex aspects of SRCs remain unresolved. Paradoxically, there is no clear-cut definition for this injury type, no objective diagnostic criteria and consensus management strategies that would account for the young athlete's age.
Very mild symptoms, the lack of specific presenting complaints and a relatively short recovery period in the absence of medication therapy foster a misconception about the insignificant impact of brain concussion on the young athlete's health. There is convincing evidence accumulated to date that even a single SRC may adversely affect academic achievement; repeated SRCs dramatically increase the risk of academic performance decline [3]. Children are at particularly high risk for long-term sequelae after SRC, especially if another episode of brain concussion occurs during the recovery period. $[4 ; 5]$. Sports medicine physicians are faced with a multitude of SRC-related questions that need to be addressed.

One of them is the incidence of brain concussions. SRC statistics cited in the literature traditionally refers to the American population of young athletes, largely due to the abundance of 
data generated from large sample sizes; in the USA, there are 1.1 to 1.9 million SRC reported cases among children annually [6]. According to other sources, the annual incidence of SRC among athletes varies from 1.6 to 3.8 million a year, being the second common cause of head injury after car accidents [7]. These statistics include college and school athletes and recreational injuries sustained during recreational activities (as opposed to practice and competition). Recent epidemiology studies have reported a surge in SRC incidence. In 2006, there were 569.4 SRCs per 100,000 injuries; in 2012 their number increased to 807.9 per 100,000 injuries [8]. This increase may be explained by but is not limited to the growing attention to SRC from doctors, coaches and parents [9]. Some amendments to legislation and socioeconomic factors discussed in [10; 11] may, too, have contributed to the active reporting of SRCs.

Although it is well known that about $70 \%$ of injuries are sustained by children under 19 years [12], until recently pediatric and adolescent SRCs were considered a minor injury. It was argued that SRCs are well compensated by physiological and adaptive resources, and their long-term effects are rare and/ or mild [13]. The argumentation was based on multiple clinical studies which reported obvious clinical symptoms or signs of neuropsychological disturbance after SRC in only a small proportion of the affected children [14].

Innovative diagnostic approaches, experimental, clinical, functional and neurophysiological studies of the brain increasingly suggest that conventional methods of clinical assessment are insufficient to detect and differentiate between subtle and heterogenous pathologies associated with SRC, especially in children. There is mounting evidence that SRC may have long-term effects on pediatric and adolescent health that persist past recovery. Most clinicians use commercial tests like ImPACT or SCAT for the clinical evaluation of SRC. Indeed, these pediatric tests have a number of indisputable advantages over baseline concussion tests, but studies have demonstrated their insufficient reliability and sensitivity for detecting SRC and predicting its sequelae that develop after the acute phase of the injury $[1 ; 15 ; 16]$.

Many researchers have convincingly demonstrated that most SRCs sustained by athletes of any age are not reported to healthcare providers. There are a few major reasons for that. Coaches do not always pay careful attention to the symptoms experienced by players; athletes do not know much about this type of injury or tend to underreport any health-related issues out of fear of being suspended from practice or competitions, etc. According to [17], 40 to $76 \%$ of young athletes attempt to conceal their injuries. According to [18], up to $80 \%$ of adolescent rugby players do not report their injuries or return to active training before making a complete recovery.

The incidence of SRC depends on the type of sports. The most injurious sport is American football. Lacrosse, ice hockey, martial arts, snowboarding and some other kinds of sports, including contact sports, are associated with high risk of SRC [5].

Pathophysiologically, SRCs is characterized by temporary neuronal and axonal dysfunction and impairments of the vascular network of the brain due to a cerebrospinal fluid shock wave and rotational mechanism; this impacts neurotransmission and neurometabolism. Besides, SRC can provoke a petechial hemorrhage around the Sylvian aqueduct [19]. Recent studies conducted in different parts of the world have paved the way to understanding fundamental SRC-inducing biokinetic mechanisms. The most crucial of them are head accelerations and decelerations, which usually alternate rapidly during the impact, and head rotation [20]. SRCs are thought to occur due to a direct blow/impact to the head. Importantly, SCRs can be caused by blows to other parts of the body if the applied force is transmitted to the head [1]. Weak neck muscles typically seen in women and children might be critical for a concussion. Some authors think that children are at greater risk for SRC because of weak neck muscles as they cannot dampen the impact to the head [21].

Pediatricians have long known that vigorous accelerationdeceleration of the head in children under 5 years often has dramatic consequences and provokes the so-called shaken baby syndrome. The term whiplash shaken infant syndrome (WSIS) was coined to describe a diagnostically important combination of symptoms, including retinal hemorrhage, subdural and/or subarachnoid hemorrhage with or without mild injury to the skull [22].

Unlike older children, the brain of younger children has a number of physiological characteristics predisposing to a dramatic clinical picture after SRC. A big head and weak neck muscles render a child vulnerable to the impact of acceleration and deceleration forces during SRC. Incomplete myelination and highly hydrophilic brain tissue typical for young age also significantly increase the risk of SRC during rapid or sudden head acceleration, deceleration and rotation [23].

Damage to the myelin sheath impairs transmission of nerve impulses and makes the brain more susceptible to injury during repeated impacts. This fact has been proved for hypoxicischemic brain injury and, more specifically, stroke in adult patients. There are ample reports that a past history of brain concussion increases the risk of a repeated concussion 2-5.8-fold [24; 25]. According to experts, repeated SRCs significantly contribute to the development of delayed complications and shape the pattern of recovery [5].

Being a highly heterogeneous group of pathologies, brain concussions are considered minor traumatic brain injuries. The underlying pathophysiology and clinical manifestations suggest that every SRC is unique and is characterized by a wide palette of symptoms ranging in severity. The diversity of SRC manifestations, which often overlap with the symptoms of other conditions, poses a diagnostic difficulty. Neuroimaging techniques (MRI, CT) used in clinical practice do not detect any pathological transformations in the brain after a concussion. However, these techniques help to differentiate SRC from other conditions with similar presentations.

Recent decades have witnessed multiple attempts to create a detailed description and a classification of SRC symptoms in different age groups of athletes involved in various sports. All $\mathrm{SRC}$ symptoms can be categorized into somatic, behavioral and cognitive.

The list of somatic SRC symptoms includes headache, nausea, vomiting, blurred vision, eye floaters, balance problems, increased sensitivity to light or noise, and tinnitus.

Among the behavioral and emotional effects of SRC are sleep disturbances, sleepiness, fatigue, irritability, anxiety, and depression.

The group of cognitive symptoms comprises difficulty concentrating or remembering things, slow reaction time, etc. [26].

A systematic review has analyzed the typical signs of SRC described in the literature [2]. The following manifestations were identified as common for athletes:

- observed and documented disorientation/confusion immediately after injury;

- inability to maintain balance within $24 \mathrm{~h}$ after injury;

- slow reaction time within 2 days after injury and/or

- impaired verbal learning and memory within 2 days after injury.

Owing to the technological advancements in neuroimaging, it is now possible to objectively assess the effects of injury on 
the brain. According to the currently held view, the definition of brain concussion should be limited to conditions caused by biomechanical exposure and not accompanied by structural changes in the brain. However, there are published diffusion tensor imaging data demonstrating the presence of microstructural brain pathology (slightly disrupted integrity of long white matter tracts, diapedesis hemorrhage) even after minor TBI and suspected SRC. It is hypothesized that such microchanges may be a sign of minimal TBI, but their clinical significance remains unclear

Nevertheless, research into functional connectivity of the brain suggests that SRC and subconcussive impacts exert a negative effect on neuronal communication in young athletes. For example, a diffusion tensor imaging study [27] revealed that whole-brain fractional anisotropy was significantly increased in adolescent athletes 6 months after brain concussion, suggesting changes to myelination and fiber density [28]. At the same time, despite the disrupted integrity of the white matter inferred from the level of fractional anisotropy in the acute injury phase, children were able to recover the normal values of the measured parameters 6 months after injury [29]. This discrepancy complicates clinical interpretation, dictating the need for further research.

Some valuable data have been generated by neurometabolic studies. Adult athletes with SRC are reported to have elevated glutamate [30], choline [31], creatinine [32] and low $\mathrm{N}$-acetylaspartate [32]. These compounds are important participants of brain metabolism; the levels of their expression correlate with neuropsychological performance [33] and results of experimental tests conducted among athletes [31]. Studies looking into the neurometabolism of children with SRC are scarce. One of them describes age-dependent changes in the metabolic profiles of children [34]. PET studies have confirmed considerable functional shifts in brain metabolism among children with sustained SRC. For example, initially excessive consumption of glucose after injury is followed by an "energy crisis" [35].

The growing interest in brain metabolism is predicated on the idea of using biomarkers in the diagnostics of brain disorders. This idea is supported by compelling scientific evidence and the potential of diagnostic agents demonstrated by stroke studies. There are promising data on the role of neuromarkers in TBI. For example, it has been established that impulse transmission between neurons is driven by changes in the transmembrane potential regulated by ion channels and glutamate receptors. The latter participate in most excitation pathways of the brain and play the key role in neuron plasticity, adaptation, learning, and memory [36].

During the acute TBI phase or axonal injury, massive amounts of glutamate are released into the synaptic cleft, initiating the activation of AMPA receptors that mediate excitation. The $\mathrm{N}$-terminal domain of AMPAR gets cleaved by extracellular proteases, permeates the disrupted blood-brain barrier and enters the bloodstream. The product of AMPAR degradation, the AMPA-peptide, can be detected in the blood. Blood levels of AMPA-peptide were measured in 84 American football athletes as part of a complex diagnostic procedure which included neurocognitive testing and neuroimaging. This study conducted in the USA demonstrated that subjects with SRC had reduced visual memory, low ImPACT scores and elevated levels of the AMPA-peptide. During a 1.5-year-long follow-up, only 18 of 33 athletes recovered normal levels of the peptide and were able to resume active training [37].

In addition to glutamate-associated markers, some other compounds have been proposed for the assessment of brain concussions: S100, glial fibrillary acidic protein, neurotrophic factors, creatinine kinases, etc. However, their practical value as diagnostic markers of SRC in young athletes has not been confirmed. Objective diagnostic criteria for concussions and health assessment criteria for athletes undergoing rehabilitation are yet to be found.

One of the hypothesized pathophysiological mechanisms of $\mathrm{SRC}$ is a cerebrovascular reactivity disturbance. It is reported that 16 to 22-year-old athletes with SRC recover from hypoand hyperventilation more slowly than their healthy peers [38]. SRC may cause chronic cerebrovascular dysfunction. A study describes a significant reduction in cerebral blood flow a month after injury in 11 to 15-year-old children [39]. Their behavioral symptoms completely resolved 2 weeks after injury, but cerebral blood flow disturbances persisted in $64 \%$ of the participants. Thirty days after injury, all of the examined children performed well in neuropsychological tests, but 36\% of them still had cerebrovascular dysfunction. Pronounced cerebrovascular dysfunction can persist for up to 12 months after injury in athletes who show no clinical symptoms of concussion and perform well in the offered tests [40]. This suggests formation of a long physiologically vulnerable period after SRC when a recurrent event, which does not have to be a biomechanical impact, can increase the risk of developing long-term adverse effects [1].

Research into neuroelectric function of the brain holds promise for shedding light on SRC-induced neurophysiological changes. The highest specificity and sensitivity are demonstrated by the event-related potentials technique. Children with brain concussion exhibit deficits in attention and executive control and are less aware of mistakes they make [41]. Even a single concussion can provoke profound changes in neuroelectric brain function, causing attention deficit, especially in cognitively demanding circumstances [42].

Summing up the above facts, SRC can provoke serious neurophysiological changes in children that can be detected by modern diagnostic tools; however, the neuroanatomic consequences of SRC remain unstudied. Despite some morphological and functional differences, the pathophysiological picture of SRC in young as well as adult athletes is quite distinct and manifests as persistent changes to functional connectivity, cerebral blood flow and neuroelectric function of the brain.

Age is a significant factor for SRC outcomes A series of studies have shown that children recover at slower pace than adults [43; 44]. Longitudinal clinical studies of SRC, which generally report optimistic outcomes, suggest that children under 10 years of age are at significantly greater risk of delayed SRC complications [14; 45]. Extensive research emphasizes the importance of recognizing prepubertal children (under 10 years) as a separate age group that is at high risk of persistent neuropsychological and neuropsychiatric impairments. But careful attention should be paid to young athletes' health throughout puberty because adolescent athletes recover at slower pace than adults [46; 47].

There is an opinion that this vulnerability of young athletes is largely determined by some age-related aspects of myelination and development of functional connectivity in maturing and developing frontal regions of the young brain [48; 49]. However, it is not shared by everyone in the scientific community. $A$ team of 11 experts led by F. P. Rivara has analyzed a vast array of publications released in 1980-2018 and concluded that there is no convincing evidence that young athletes are more susceptible to SRC than adults [5]. At the same time, the experts are unanimous in stating that the quality of research studies has changed significantly over the past years, which complicates comparison and interpretation of data yielded by of research studies from different time periods. 
Traditionally, the contribution of sex differences to SRC outcomes remains the subject of heated debate. Some authors point to the higher incidence of SRC in young female students [50; 51]; these findings are supported by the conclusion of the expert panel [5]. According to the literature, the frequency and intensity of clinical symptoms and the rate of unfavorable outcomes are generally higher for female underage athletes than for young male athletes [52; 53]. This could be explained by the well-established fact that females have weaker neck muscles rendering them more susceptible to biomechanical injury [54]. At the same time, young females pay more attention to their health and promptly report their symptoms to coaches or medical personnel [55]. It is only fair to say that weakness of neck muscles is typical for children, and some specialists believe that sports training programs should include special exercise for neck strengthening that can protect against traumatic injury. However, we found no studies comparing the incidence and severity of SRC consequences between athletes and non-athletes that would factor in age.

\section{CONCLUSION}

Pediatric and adolescent sport-related brain concussions pose a challenge to contemporary science in general and sports medicine in particular. Recent research suggests that SRCs lead to profound changes in the body and require improved diagnostic approaches, as well as refined preventive and treatment strategies. The following problems remain unsolved to this day and demand special attention:

- new methods are needed for SRC diagnostics and the dynamic assessment of the brain's functional state that would account for the age-related characteristics of young athletes; such methods could be based on neuroimaging techniques like functional magnetic resonance imaging, magnetic resonance spectroscopy, diffusion tensor imaging, functional magnetoencephalography, transcranial magnetic stimulation, etc.

- it is important to continue the search for and the development of special approaches to medication therapy and metabolic correction of typical delayed complications of SRC in young athletes, such as functional connectivity disorders, neurometabolic and circulatory changes, cognitive and sensor impairments;

- there is a need for training programs, protocols for SRC rehabilitation and medical surveillance to regulate return to active practice after injury;

- information leaflets for coaches should be prepared explaining what measures need to be taken if a young athlete sustains SRC and how SRC can be prevented.

\section{References}

1. McCrory P, Meeuwisse W, Dvorak J, et al. Consensus statement on concussion in sport-the 5th international conference on concussion in sport held in Berlin. Br J Sports Med. 2016; 51 (11): 838-47.

2. Giza CC, Hovda DA. The new neurometabolic cascade of concussion. Neurosurgery. 2014; 75 (suppl 4): S24-S33.

3. Neelakantan M, Ryali B, Cabral MD, Harris A, McCarroll J, Patel DR. Academic Performance Following Sport-Related Concussions in Children and Adolescents: A Scoping Review. Int J Environ Res Public Health. 2020; 17: 7602.

4. Davis GA, AndersonV, Babl FE, Gioia, GA, Giza CC, Meehan W, et al. What is the difference in concussion management in children as compared with adults? A systematic review. Br J Sports Med. 2017; 51: 949-57.

5. Rivara FP, Tennyson R, Mills B, Browd SR, Emery CA, Gioi G, et al. Consensus Statement on Sports-Related Concussions in Youth Sports. JAMA Pediatr. 2020; 174 (1): 79-85.

6. Bryan MA, Rowhani-Rahbar A, Comstock RD, Rivara F. Sportsand recreation-related concussions in US youth. Pediatrics. 2016 138: e20154635

7. Zuckerman SL, Kerr ZY, Yengo-Kahn A, Wasserman E, Covassin T, Solomon GS. Epidemiology of sports-related concussion in NCAA athletes from 2009-2010 to 2013-2014: incidence, recurrence, and mechanisms. Am J Sports Med. 2015; 43: 2654-62.

8. Cancelliere C, Coronado VG, Taylor CA, Xu L. Epidemiology of isolated versus nonisolated mild traumatic brain injury treated in emergency departments in the United States, 2006-2012 sociodemographic characteristics. J Head Trauma Rehabil. 2017; 32 (4): E37-E46

9. Kerr ZY, Yeargin S, Valovich McLeod TC, Nittoli VC, Mensch J, Dodge $\mathrm{T}$, et al. Comprehensive coach education and practice contact restriction guidelines result in lower injury rates in youth American football. Orthopaedic Journal of Sports Medicine. 2015; 3 (7): 2325967115594578 . DOI: 10.1177/2325967115594578. PMID: 26674011; PMCID: PMC4622331.

10. Bompadre V, Jinguji TM, Yanez ND, Satchell EK, Gilbert K, Burton M, et al. Washington State's Lystedt law in concussion documentation in Seattle public high schools. Journal of Athletic Training. 2014; 49 (4): 486-92.

11. Yang J, Comstock RD, Yi H, Harvey HH, Xun P. New and recurrent

concussions in high-school athletes before and after traumatic brain injury laws, 2005-2016. American Journal of Public Health. 2017; e1-e7.

12. Coronado VG, Haileyesus T, Cheng TA, Bell JM, HaarbauerKrupa J, Lionbarger MR, et al. Trends in sports- and recreationrelated traumatic brain injuries treated in US emergency departments: the National Electronic Injury Surveillance SystemAll Injury Program (NEISS-AIP) 2001-2012. J Head Trauma Rehabil. 2015; 30 (3): 185-97.

13. Carroll LJ, Cassidy JD, Holm L, Kraus J, Coronado VG Methodological issues and research recommendations for mild traumatic brain injury: the WHO collaborating centre task force on mild traumatic brain injury. J Rehabil Med. 2004; S (43): 113-25.

14. Babikian T, Satz P, Zaucha K, Light R, Lewis RS, Asarnow RF. The UCLA longitudinal study of neurocognitive outcomes following mild pediatric traumatic brain injury. J Int Neuropsychol Soc. 2011; 17 (5): 886-95.

15. Resch J, Driscoll A, McCaffrey N, Brown C, Ferrara MS, Macciocchi S, et al. ImPact test-retest reliability: reliably unreliable? J Athl Train. 2013; 48 (4): 506-11.

16. Bruce J, Echemendia R, Meeuwisse W, Comper P, Sisco A. 1 year test-retest reliability of ImPACT in professional ice hockey players. Clin Neuropsychol. 2014; 28 (1): 14-25.

17. Prasad MR, Swank PR, Ewing-Cobbs L. Long-term school outcomes of children and adolescents with traumatic brain injury. J Head Trauma Rehabil. 2017; 32: E24-E32.

18. Alexander DG, Shuttleworth-Edwards AB, Kidd M, Malcolm CM. Mild traumatic brain injuries in early adolescent rugby players: Long-term neurocognitive and academic outcomes. Brain Injury. 2015; 29: 1113-25.

19. Gusev El, Skvorcova VI. Ishemija golovnogo mozga. M.: Medicina, 2001; 328 c. Russian.

20. Ommaya AK, Gennarelli TA. Cerebral concussion and traumatic unconsciousness. Correlation of experimental and clinical observations of blunt head injuries. Brain. 1974; 97 (4): 633-54.

21. Buzzini SR, Guskiewicz KM. Sport-related concussion in the young athlete. Curr Opin Pediatr. 2006; 18 (4): 376-82.

22. Rumjancev AG, Dreval ON, Feniksov VM. Sindrom «Shaken Baby» : diagnostika, lechenie, profilaktika. Voprosy prakticheskoj pediatrii. 2007; 2 (2): 23-29. Russian. 
23. Adam JO, Jai S, Kshitij M. Parenchymal brain injuries in abusive head trauma. Pediatr Radiol. 2021; Feb 27.

24. Emery C, Kang J, Shrier I, Goulet C, Hagel B, Benson B, et al. Risk of injury associated with bodychecking experience among youth hockey players. Can Med Assoc J. 2011; 183: 1249-56.

25. Hollis SJ, Stevenson MR, Mclntosh AS. Incidence, Risk, and Protective Factors of Mild Traumatic Brain Injury in a Cohort of Australian Nonprofessional Male Rugby Players. Am J Sports Med. 2009; Dec; 37 (12): 2328-33.

26. Halstead ME, Walter KD, Moffatt $\mathrm{K}$, Council on sports medicine and fitness. Sport-Related Concussion in Children and Adolescents. Pediatrics December. 2018; 142 (6): e20183074.

27. Virji-Babul N, Borich MR, Makan N, Moore T, Frew K, Emery CA, et al. Diffusion tensor imaging of sports-related concussion in adolescents. Pediatr Neurol. 2013; 48 (1): 24-29.

28. Feldman HM, Yeatman JD, Lee ES, Barde LH, Gaman-Bean S. Diffusion tensor imaging: a review for pediatric researchers and clinicians. J Dev Behav Pediatr. 2010; 31 (4): 346-56.

29. Van BL, Ghesquière P, Lagae L, De SB. Arithmetic difficulties in children with mild traumatic brain injury at the subacute stage of recovery. Dev Med Child Neurol. 2015; 57 (11): 1042-8.

30. Gasparovic C, Yeo R, Mannell M, Ling J, Elgie R, Phillips J, et al. Neurometabolite concentrations in gray and white matter in mild traumaticbrain injury: an $1 \mathrm{H}$-magnetic resonance spectroscopy study. J Neurotrauma. 2009; 26 (10): 1635-43.

31. Yeo RA, Phillips JP, Jung RE, Brown AJ, Campbell RC, Brooks WM. Magnetic resonance spectroscopy detects brain injury and predicts cognitive functioning in children with brain injuries. $J$ Neurotrauma. 2006; 23 (10): 1427-35.

32. Vagnozzi R, Signoretti S, Floris R, Marziali S, Manara M, Amorini AM, et al. Decrease in $\mathrm{N}$-acetylaspartate following concussion may be coupled to decrease in creatine. J Head Trauma Rehabil. 2013; 28 (4): 284-92.

33. Babikian T, Freier MC, Ashwal S, Riggs ML, Burley T, Holshouser BA. MR spectroscopy: predicting long-term neuropsychological outcome following pediatric TBI. J Magn Reson Imaging. 2006; 2 (4): 801-11.

34. McCrea M, Meier T, Huber D, Ptito A, Bigler E, Debert CT, jet al. Role of advanced neuroimaging, fluid biomarkers and genetic testing in the assessment of sport-related concussion: a systematic review. Br J Sports Med. 2017; 51 (12): 919-29.

35. Halstead ME, Walter KD. Clinical report-sport-related concussion in children and adolescents. Pediatrics. 2010; 126 (3): 597-615.

36. Dambinova SA, Shikuev AV, Weissman JD, Mullins CD. AMPAR Peptide Values in Blood of Nonathletes and Club Sport Athletes With Concussions. Military Medicine. 2013; 178 (3): 285-90.

37. Dambinova KT, Aliev EV, Bondarenko GV, Ponomarev AA Skoromec AP, Skoromec TA, i dr. Biomarkery ishemii golovnogo mozga kak novyj metod dokazatel'stva jeffektivnosti nejrocitoprotektorov. Zhurnal nevrologii i psihiatrii im. S. S. Korsakova. 2017; 117 (5): 62-67. Russian.

38. Len TK, Neary JP, Asmundson GJG, Goodman DG, Bjornson B, Bhambhani YN. Cerebrovascular reactivity impairment after sport-induced concussion. Med Sci Sports Exerc. 2011; 43 (12): 2241-8.

39. Maugans TA, Farley C, Altave M, Leach J, Cecil KM. Pediatric sports-related concussion produces cerebral blood flow alterations. Pediatrics. 2012; 129 (1): 28-37.

40. Wang Y, West JD, Bailey JN, Westfall DR, Xiao H, Arnold TW, et

\section{Литература}

1. McCrory P, Meeuwisse W, Dvorak J, et al. Consensus statement on concussion in sport-the 5th international conference on concussion in sport held in Berlin. Br J Sports Med. 2016; 51 (11): 838-47.

2. Giza CC, Hovda DA. The new neurometabolic cascade of concussion. Neurosurgery. 2014; 75 (suppl 4): S24-S33.

3. Neelakantan M, Ryali B, Cabral MD, Harris A, McCarroll J, Patel DR. Academic Performance Following Sport-Related Concussions in Children and Adolescents: A Scoping Review. Int J Environ Res Public Health. 2020; 17: 7602. al. Decreased cerebral blood flow in chronic pediatric mild TBI: an MRI perfusion study. Dev Neuropsychol. 2015; 40 (1): 40-44.

41. Moore DR, Pindus DM, Raine LB, Drollette ES, Scudder MR, Ellemberg $\mathrm{D}$, et al. The persistent influence of concussion on attention, executive control, and neuroelectric function in preadolescent children. Int J Psychophysiol. 2016; 99: 85-95.

42. Moor RD, Jacob JK, Ellemberg D. The long-term outcomes of sport-related concussion in pediatric populations. Int $J$ Psychophysiol. 2018; 132 (Pt A): 14-24.

43. Baillargeon $A$, Lassonde $M$, Leclerc $S$, Ellemberg D. Neuropsychological and neurophysiological assessment of sport concussion in children, adolescents and adults. Brain Inj. 2012; 26 (3): 211-20

44. Nelson LD, Guskiewicz KM, Barr WB, Hammeke TA, Randolph C, Ahn KW, aet al. Age differences in recovery after sport-related concussion: a comparison of high school and collegiate athletes. J Athl Train. 2016; 51 (2): 142-52.

45. Hessen E, Nestvold K, Anderson V. Neuropsychological function 23 years after mild traumatic brain injury: a comparison of outcome after pediatri and adult head injuries. Brain Inj. 2007; 21 (9): 963-79.

46. Babcock L, Byczkowski T, Wade SL, Ho M, Mookerjee S, Bazarian JJ. Predicting postconcussion syndrome after mild traumatic brain injury in children andadolescents who present to the emergency department. JAMA Pediatr. 2013; 167 (2): 156-61.

47. Baillargeon A, Lassonde M, Leclerc S, Ellemberg D. Neuropsychological and neurophysiological assessment of sport concussion in children, adolescents and adults. Brain Inj. 2012; 26 (3): $211-20$

48. Prins ML, Giza CC, Repeat traumatic brain injury in the developing brain. Int J Dev Neurosci. 2012; 30 (3): 185-90.

49. Moore RD, Pindus DM, Drolette ES, Scudder MR, Raine LB, Hillman $\mathrm{CH}$. The persistent influence of pediatric concussion on attention and cognitive control during flanker performance. Biol Psychol. 2015; 109: 93-102.

50. Gessel LM, Fields SK, Collins CL, Dick RW, Comstock RD. Concussions among United States high school and collegiate athletes. J Athl Train. 2007; 42 (4): 495-503.

51. Covassin T, Moran R, Elbin RJ. Sex differences in reported concussion injury rates and time loss from participation: an update of the National Collegiate Athletic Association Injury Surveillance Program from 2004-2005 through 2008-2009. $J$ Athl Train. Large study summarizing sex differences in concussion rates and recovery after SRC in collegiate athletes. 2016; 51: 189-94.

52. Ono KE, Burns TG, Bearden DJ, McManus SM, King H, Reisner A. Sex-based differences as a predictor of recovery trajectories in young athletes after a sports-related concussion. Am J Sports Med. 2016; 44 (3): 748-52.

53. Tanveer SR, Zecavati N, Delasobera EB, Oyegbile TO. Gender differences in concussion and post-injury cognitive findings in an older and younger pediatric population. Pediatr Neurol. 2017; 70: 40-49.

54. Caccese JB, Kaminski TW. Minimizing head acceleration in soccer: a review of the literature. Sports Medicine. 2016; 46 (11): 1591-604.

55. Wallace J, Covassin T, Beidler E. Sex differences in high school athletes' knowledge of sport-related concussion symptoms and reporting behaviors. J Athl Train. 2017; 52: 682-8.
4. Davis GA, AndersonV, Babl FE, Gioia, GA, Giza CC, Meehan W, et al. What is the difference in concussion management in children as compared with adults? A systematic review. Br J Sports Med. 2017; 51: 949-57.

5. Rivara FP, Tennyson R, Mills B, Browd SR, Emery CA, Gioi G, et al. Consensus Statement on Sports-Related Concussions in Youth Sports. JAMA Pediatr. 2020; 174 (1): 79-85.

6. Bryan MA, Rowhani-Rahbar A, Comstock RD, Rivara F. Sportsand recreation-related concussions in US youth. Pediatrics. 2016; 138: e20154635. 
7. Zuckerman SL, Kerr ZY, Yengo-Kahn A, Wasserman E, Covassin T, Solomon GS. Epidemiology of sports-related concussion in NCAA athletes from 2009-2010 to 2013-2014: incidence, recurrence, and mechanisms. Am J Sports Med. 2015; 43: 2654-62.

8. Cancelliere C, Coronado VG, Taylor CA, Xu L. Epidemiology of isolated versus nonisolated mild traumatic brain injury treated in emergency departments in the United States, 2006-2012: sociodemographic characteristics. J Head Trauma Rehabil. 2017; 32 (4): E37-E46.

9. Kerr ZY, Yeargin S, Valovich McLeod TC, Nittoli VC, Mensch J, Dodge $\mathrm{T}$, et al. Comprehensive coach education and practice contact restriction guidelines result in lower injury rates in youth American football. Orthopaedic Journal of Sports Medicine. 2015 3 (7): 2325967115594578 . DOI: 10.1177/2325967115594578. PMID: 26674011; PMCID: PMC4622331.

10. Bompadre V, Jinguji TM, Yanez ND, Satchell EK, Gilbert K, Burton $\mathrm{M}$, et al. Washington State's Lystedt law in concussion documentation in Seattle public high schools. Journal of Athletic Training. 2014; 49 (4): 486-92.

11. Yang J, Comstock RD, Yi H, Harvey HH, Xun P. New and recurrent concussions in high-school athletes before and after traumatic brain injury laws, 2005-2016. American Journal of Public Health. 2017; e1-e7.

12. Coronado VG, Haileyesus T, Cheng TA, Bell JM, HaarbauerKrupa J, Lionbarger MR, et al. Trends in sports- and recreationrelated traumatic brain injuries treated in US emergency departments: the National Electronic Injury Surveillance SystemAll Injury Program (NEISS-AIP) 2001-2012. J Head Trauma Rehabil. 2015; 30 (3): 185-97.

13. Carroll LJ, Cassidy JD, Holm L, Kraus J, Coronado VG. Methodological issues and research recommendations for mild traumatic brain injury: the WHO collaborating centre task force on mild traumatic brain injury. J Rehabil Med. 2004; S (43): 113-25.

14. Babikian T, Satz P, Zaucha K, Light R, Lewis RS, Asarnow RF. The UCLA longitudinal study of neurocognitive outcomes following mild pediatric traumatic brain injury. J Int Neuropsychol Soc. 2011; 17 (5): 886-95.

15. Resch J, Driscoll A, McCaffrey N, Brown C, Ferrara MS, Macciocchi S, et al. ImPact test-retest reliability: reliably unreliable? J Athl Train. 2013; 48 (4): 506-11.

16. Bruce J, Echemendia R, Meeuwisse W, Comper P, Sisco A. 1 year test-retest reliability of ImPACT in professional ice hockey players. Clin Neuropsychol. 2014; 28 (1): 14-25.

17. Prasad MR, Swank PR, Ewing-Cobbs L. Long-term school outcomes of children and adolescents with traumatic brain injury. J Head Trauma Rehabil. 2017; 32: E24-E32.

18. Alexander DG, Shuttleworth-Edwards AB, Kidd M, Malcolm CM Mild traumatic brain injuries in early adolescent rugby players: Long-term neurocognitive and academic outcomes. Brain Injury. 2015; 29: 1113-25.

19. Гусев Е. И., Скворцова В. И. Ишемия головного мозга. М.: Медицина, 2001; 328 с.

20. Ommaya AK, Gennarelli TA. Cerebral concussion and traumatic unconsciousness. Correlation of experimental and clinical observations of blunt head injuries. Brain. 1974; 97 (4): 633-54.

21. Buzzini SR, Guskiewicz KM. Sport-related concussion in the young athlete. Curr Opin Pediatr. 2006; 18 (4): 376-82.

22. Румянцев А. Г., Древаль О. Н., Фениксов В. М. Синдром "Shaken Baby» : диагностика, лечение, профилактика. Вопросы практической педиатрии. 2007; 2 (2): 23-29.

23. Adam JO, Jai S, Kshitij M. Parenchymal brain injuries in abusive head trauma. Pediatr Radiol. 2021; Feb 27

24. Emery C, Kang J, Shrier I, Goulet C, Hagel B, Benson B, et al Risk of injury associated with bodychecking experience among youth hockey players. Can Med Assoc J. 2011; 183: 1249-56.

25. Hollis SJ, Stevenson MR, Mclntosh AS. Incidence, Risk, and Protective Factors of Mild Traumatic Brain Injury in a Cohort of Australian Nonprofessional Male Rugby Players. Am J Sports Med. 2009; Dec; 37 (12): 2328-33.

26. Halstead ME, Walter KD, Moffatt K, Council on sports medicine and fitness. Sport-Related Concussion in Children and Adolescents. Pediatrics December. 2018; 142 (6): e20183074.

27. Virji-Babul N, Borich MR, Makan N, Moore T, Frew K, Emery CA et al. Diffusion tensor imaging of sports-related concussion in adolescents. Pediatr Neurol. 2013; 48 (1): 24-29.

28. Feldman HM, Yeatman JD, Lee ES, Barde LH, Gaman-Bean S. Diffusion tensor imaging: a review for pediatric researchers and clinicians. J Dev Behav Pediatr. 2010; 31 (4): 346-56.

29. Van BL, Ghesquière $P$, Lagae L, De SB. Arithmetic difficulties in children with mild traumatic brain injury at the subacute stage of recovery. Dev Med Child Neurol. 2015; 57 (11): 1042-8.

30. Gasparovic C, Yeo R, Mannell M, Ling J, Elgie R, Phillips J, et al. Neurometabolite concentrations in gray and white matter in mild traumaticbrain injury: an $1 \mathrm{H}$-magnetic resonance spectroscopy study. J Neurotrauma. 2009; 26 (10): 1635-43.

31. Yeo RA, Phillips JP, Jung RE, Brown AJ, Campbell RC, Brooks WM. Magnetic resonance spectroscopy detects brain injury and predicts cognitive functioning in children with brain injuries. $J$ Neurotrauma. 2006; 23 (10): 1427-35.

32. Vagnozzi R, Signoretti S, Floris R, Marziali S, Manara M, Amorini AM, et al. Decrease in $\mathrm{N}$-acetylaspartate following concussion may be coupled to decrease in creatine. J Head Trauma Rehabil. 2013; 28 (4): 284-92.

33. Babikian T, Freier MC, Ashwal S, Riggs ML, Burley T, Holshouser BA. MR spectroscopy: predicting long-term neuropsychological outcome following pediatric TBI. J Magn Reson Imaging. 2006; 2 (4): 801-11.

34. McCrea M, Meier T, Huber D, Ptito A, Bigler E, Debert CT, jet al. Role of advanced neuroimaging, fluid biomarkers and genetic testing in the assessment of sport-related concussion: a systematic review. Br J Sports Med. 2017; 51 (12): 919-29.

35. Halstead ME, Walter KD. Clinical report-sport-related concussion in children and adolescents. Pediatrics. 2010; 126 (3): 597-615.

36. Dambinova SA, Shikuev AV, Weissman JD, Mullins CD. AMPAR Peptide Values in Blood of Nonathletes and Club Sport Athletes With Concussions. Military Medicine. 2013; 178 (3): 285-90.

37. Дамбинова К. Т., Алиев Е. В., Бондаренко Г. В., Пономарев А. А., Скоромец А. П., Скоромец Т. А. и др. Биомаркеры ишемии головного мозга как новый метод доказательства эффективности нейроцитопротекторов. Журнал неврологии и психиатрии им. С. С. Корсакова. 2017; 117 (5): 62-67.

38. Len TK, Neary JP, Asmundson GJG, Goodman DG, Bjornson B, Bhambhani YN. Cerebrovascular reactivity impairment after sport-induced concussion. Med Sci Sports Exerc. 2011; 43 (12): 2241-8

39. Maugans TA, Farley C, Altave M, Leach J, Cecil KM. Pediatric sports-related concussion produces cerebral blood flow alterations. Pediatrics. 2012; 129 (1): 28-37.

40. Wang Y, West JD, Bailey JN, Westfall DR, Xiao H, Arnold TW, et al. Decreased cerebral blood flow in chronic pediatric mild TBI: an MRI perfusion study. Dev Neuropsychol. 2015; 40 (1): 40-44.

41. Moore DR, Pindus DM, Raine LB, Drollette ES, Scudder MR, Ellemberg D, et al. The persistent influence of concussion on attention, executive control, and neuroelectric function in preadolescent children. Int J Psychophysiol. 2016; 99: 85-95.

42. Moor RD, Jacob JK, Ellemberg D. The long-term outcomes of sport-related concussion in pediatric populations. Int $J$ Psychophysiol. 2018; 132 (Pt A): 14-24.

43. Baillargeon $A$, Lassonde $M$, Leclerc $S$, Ellemberg $D$. Neuropsychological and neurophysiological assessment of sport concussion in children, adolescents and adults. Brain Inj. 2012; 26 (3): 211-20.

44. Nelson LD, Guskiewicz KM, Barr WB, Hammeke TA, Randolph C, Ahn KW, aet al. Age differences in recovery after sport-related concussion: a comparison of high school and collegiate athletes. J Athl Train. 2016; 51 (2): 142-52.

45. Hessen E, Nestvold K, Anderson V. Neuropsychological function 23 years after mild traumatic brain injury: a comparison of outcome after pediatri and adult head injuries. Brain Inj. 2007; 21 (9): 963-79.

46. Babcock L, Byczkowski T, Wade SL, Ho M, Mookerjee S, Bazarian JJ. Predicting postconcussion syndrome after mild traumatic brain injury in children andadolescents who present to the emergency department. JAMA Pediatr. 2013; 167 (2): 156-61.

47. Baillargeon A, Lassonde $M$, Leclerc S, Ellemberg D. Neuropsychological and neurophysiological assessment of sport 
concussion in children, adolescents and adults. Brain Inj. 2012; 26 (3): 211-20.

48. Prins ML, Giza CC, Repeat traumatic brain injury in the developing brain. Int J Dev Neurosci. 2012; 30 (3): 185-90.

49. Moore RD, Pindus DM, Drolette ES, Scudder MR, Raine LB, Hillman $\mathrm{CH}$. The persistent influence of pediatric concussion on attention and cognitive control during flanker performance. Biol Psychol. 2015; 109: 93-102.

50. Gessel LM, Fields SK, Collins CL, Dick RW, Comstock RD. Concussions among United States high school and collegiate athletes. J Athl Train. 2007; 42 (4): 495-503.

51. Covassin T, Moran R, Elbin RJ. Sex differences in reported concussion injury rates and time loss from participation: an update of the National Collegiate Athletic Association Injury Surveillance Program from 2004-2005 through 2008-2009. $\checkmark$ Athl Train. Large study summarizing sex differences in concussion rates and recovery after SRC in collegiate athletes. 2016; 51: 189-94.

52. Ono KE, Burns TG, Bearden DJ, McManus SM, King H, Reisner A. Sex-based differences as a predictor of recovery trajectories in young athletes after a sports-related concussion. Am J Sports Med. 2016; 44 (3): 748-52.

53. Tanveer SR, Zecavati N, Delasobera EB, Oyegbile TO. Gender differences in concussion and post-injury cognitive findings in an older and younger pediatric population. Pediatr Neurol. 2017; 70: 40-49.

54. Caccese JB, Kaminski TW. Minimizing head acceleration in soccer: a review of the literature. Sports Medicine. 2016; 46 (11): 1591-604.

55. Wallace J, Covassin T, Beidler E. Sex differences in high school athletes' knowledge of sport-related concussion symptoms and reporting behaviors. J Athl Train. 2017; 52: 682-8. 